\title{
Vector Specificity, Host Range, and Genetic Diversity of Tomato chlorosis virus
}

\author{
William M. Wintermantel, United States Department of Agriculture-Agricultural Research Service, Salinas, CA; \\ and Gail C. Wisler, Department of Plant Pathology, University of Florida, Gainesville
}

\begin{abstract}
Wintermantel, W. M., and Wisler, G. C. 2006. Vector specificity, host range, and genetic diversity of Tomato chlorosis virus. Plant Dis. 90:814-819.

Tomato chlorosis virus (ToCV), family Closteroviridae, genus Crinivirus, causes interveinal chlorosis, leaf brittleness, and limited necrotic flecking or leaf bronzing on tomato leaves. ToCV can cause a decline in plant vigor and reduce fruit yield. It is emerging as a serious production problem for field and greenhouse tomato growers, and has been increasing in prevalence in many parts of the world. The virus is unique among known whitefly-transmitted viruses, due to its ability to be transmitted by four whitefly vectors from two genera. Studies demonstrated that transmission efficiency and virus persistence in the vector varies significantly among the different whitefly vectors. Trialeurodes abutilonea and Bemisia tabaci biotype B are highly efficient vectors of ToCV. B. tabaci biotype A and T. vaporariorum are less efficient vectors, but are fully capable of transmission. ToCV persists for up to 5 days in $T$. abutilonea, 2 days in $B$. tabaci biotype $\mathrm{B}$, and only 1 day in $B$. tabaci biotype $\mathrm{A}$ and $T$. vaporariorum. ToCV has a moderately wide host range, infecting 24 host plant species in seven families. A portion of the coat protein coding region of five geographically diverse ToCV isolates was compared and found to be highly conserved. This information, coupled with existing information on conservation within the heat shock protein 70 homologue coding region, suggests that many ToCV isolates throughout the world are related very closely, and may have been distributed on plant material.
\end{abstract}

Additional keyword: sequence

Tomato chlorosis virus (ToCV), genus Crinivirus, family Closteroviridae, originally was identified in 1996 from greenhouse-grown tomato plants (Lycopersicon esculentum Mill.) with symptoms termed "yellow leaf disorder" from northern Florida. These tomato plants exhibited symptoms including interveinal chlorosis, leaf brittleness, and limited necrotic flecking or leaf bronzing (Fig. 1). Although symptoms on tomato were nearly identical to those associated with infection by the previously characterized crinivirus, Tomato infectious chlorosis virus (TICV), ToCV subsequently was found to be a distinct virus (29). Whereas TICV is transmitted exclusively by the greenhouse whitefly (Trialeu-

Corresponding author: W. M. Wintermantel E-mail: wwintermantel@pw.ars.usda.gov

* The $\boldsymbol{e}$-Xtra logo stands for "electronic extra" and indicates that Figures 1 and 2 appear in color in the online edition.

This project was supported by United States Department of Agriculture-Agricultural Research Service project number 5305-22000-010-00D.

New accession numbers: DQ234671, DQ234672, DQ234673, DQ234674, and DQ234675.

Accepted for publication 10 February 2006.

DOI: 10.1094/PD-90-0814

This article is in the public domain and not copyrightable. It may be freely reprinted with customary crediting of the source. The American Phytopathological Society, 2006. rodes vaporariorum Westwood), ToCV can be transmitted by $T$. vaporariorum and also by the banded wing whitefly (T. abutilonea Haldeman) and Bemisia tabaci (Gennadius) biotypes A and B (4,5). Furthermore, the two viruses can be distinguished using differential molecular probes (29).

The genome of $\mathrm{ToCV}$ is typical of criniviruses, consisting of two genomic positive-sense RNAs (28), encapsidated as long flexuous virions approximately 800 to $850 \mathrm{~nm}$ in length (13). RNA1 encodes four open reading frames (ORFs), the largest of which encode proteins associated with virus replication $(11,28)$, and RNA2 encodes up to nine ORFs encoding proteins involved in a multitude of functions, including virus encapsidation, cell-to-cell movement, membrane association, and whitefly transmission $\quad(2,3,11,16,19-$ 21,24,28,30).

$\mathrm{ToCV}$ is an emerging virus and has been detected in tomato from many parts of the world, including the United States (29), Puerto Rico (27), Europe $(1,7,14,17)$, Morocco (10), Taiwan (25), and, most recently, Israel (22). In the United States, ToCV is primarily a problem for field tomato in the southeast, particularly in Florida, but it also has been found in greenhouse production facilities throughout many parts of the country. ToCV also is increasing in prevalence throughout the Mediterranean region, having been found in numerous countries within the last 5 years. Many but not all of these outbreaks have been associated with greenhouse tomato production, where vector populations can build to high levels. In addition to tomato, ToCV has been shown to infect some cultivars of pepper (Capsicum annuum L.), resulting in symptoms of interveinal yellowing, mild leaf curling, and stunting (15).

ToCV has a relatively long latent period in infected host plants, often not inducing symptoms until 3 to 4 weeks after infection. If nursery plants are exposed to vector populations at an early age, it is possible for ToCV to be spread to new areas through movement of transplants prior to symptom development. Another potential source of $\mathrm{ToCV}$ is the presence of weed hosts near production areas. Font and colleagues (9) identified Solanum nigrum L. infected with $\mathrm{ToCV}$ in Alicante and Murcia, Spain. Other reservoir hosts near field or greenhouse production areas also may serve as sources for whitefly populations that, ultimately, can carry the virus to the crop. Like other criniviruses, ToCV is not transmitted mechanically (7); thus, it is dependent on whiteflies to spread from plant to plant.

Over the past decade, whitefly populations have been increasing throughout the world. Associated with this increase has been an emergence of numerous whiteflytransmitted criniviruses (26). Due to the increasing prevalence of criniviruses throughout the world and their impact on vegetable and fruit production, it is critical that the host range and vector relationships of these viruses be understood to develop effective and efficient management practices. To this end, we present here information on (i) the efficiency and persistence of ToCV transmission by each of four whitefly vectors, (ii) a list of plants that have been demonstrated to be hosts and nonhosts of ToCV, and (iii) a study of the relative amount of variability among ToCV isolates and, perhaps, a better understanding of factors influencing the epidemiology of ToCV.

\section{MATERIALS AND METHODS}

Virus isolates. The virus isolate used for host range and vector transmission analysis was obtained from a commercial tomato-producing greenhouse in Suwannee County, FL during January 1996, and is known as the Florida isolate (ToCV-FL; 28,29). This isolate has been maintained in tomato, Physalis wrightii Gray, and Nicotiana benthamiana Domin plants, and transferred from plant to plant via whitefly vectors, primarily B. tabaci biotype $\mathrm{B}$ and 
T. abutilonea. ToCV isolates used for sequence comparisons were obtained from symptomatic tomato plants from tomato greenhouses in Florida, Louisiana, and Colorado (29), and from field tomato plants in Puerto Rico (27) and Israel (22). These isolates were maintained at $-80^{\circ} \mathrm{C}$ as frozen plant and nucleic acid samples from previous studies. All nucleic acids were extracted by the method of Dellaporta et al. (6). Because ToCV symptoms resemble those of TICV, all field and greenhouse samples were tested initially by two or more of the following methods: nucleic acid spot hybridization with RNA probes specific to either TICV or ToCV (29), reverse-transcription polymerase chain reaction (RT-PCR) using primers that amplify either the complete 773-nucleotide (nt) ToCV coat protein (CP) gene (22) or a 325-nt section of the TICV HSP70h gene (forward: 5' AAAAAGGTGGGTCGGAGTCG 3'; reverse: 5' CGGCAGATGGTTCGTTATTATCC $3^{\prime}$ ), or by Western blot analysis using antiserum specific for TICV (8). All samples of the isolates listed above tested positive for ToCV and negative for TICV in at least two types of tests, confirming that infection was from ToCV alone, and that there was no mixed infection with TICV.

Vectors. All whitefly colonies were maintained virus-free in insect-proof cages in isolated growth rooms at temperatures ranging from 26 to $32^{\circ} \mathrm{C}$ on the hosts as described below. A colony of $T$. vaporariorum, originally collected in a greenhouse at the United States Department of Agriculture-Agricultural Research Service in Salinas, CA in the early 1960s, was reared on $P$. wrightii seedlings. T. abutilonea, originally collected in Illinois in the late 1970s, was reared on climbing nightshade (S. dulcamara L.). B. tabaci biotype A, originally collected in 1981 from cotton (Gossypium hirsutum L.) in the Imperial Valley of California, was reared on sweetpotato (Ipomoea batatas L.). B. tabaci biotype B, originally collected in 1990 from melon (Cucumis melo L.) in the Imperial Valley of California, was reared on broccoli (Brassica oleracea L.). Bemisia tabaci biotypes A and B were tested every 6 months by isozyme analysis (12) to confirm purity and prevent accidental contamination by the alternate biotype.

Virus transmission. Source plants for all transmission studies were $P$. wrightii plants, inoculated approximately 30 days earlier and expressing interveinal yellowing symptoms, a characteristic of welldeveloped ToCV infections. T. vaporariorum, $T$. abutilonea, and B. tabaci biotypes $\mathrm{A}$ and $\mathrm{B}$ were tested for their ability to transmit ToCV. Large numbers of each whitefly vector were allowed acquisition access periods (AAPs) of $24 \mathrm{~h}$ on source plants. Following virus acquisition, whiteflies were transferred to leaf cages by briefly chilling the whiteflies at $4^{\circ} \mathrm{C}$ to immobilize them. Cages containing 30 whiteflies each were used on each plant for transmission experiments. $N$. clevelandii Gray, $P$. wrightii, or $N$. benthamiana were used as test plants for studies on vector transmission. Five tests of 10 plants per replication were performed with each whitefly species to conclusively test the ability of ToCV to be transmitted by these species. The persistence of ToCV in whitefly vectors was determined by allowing whiteflies AAPs of $24 \mathrm{~h}$ on diseased plants serial transfers to virus-free indicator host seedlings, with 24-h inoculation access periods (IAPs) per each serial transfer. Following inoculation with ToCV via whiteflies, the plants were sprayed with resmethrin (Whitmire, Inc., St. Louis) to kill the whitefly vectors and placed in greenhouses. One week post inoculation, inoculated leaves were removed from plants to prevent whitefly nymphs from maturing to adults. Plants were grown in whitefly-proof screened cages in greenhouses, which were fumigated at weekly intervals with dichlorvos (Boehringer Ingelheim Inc., St. Joseph), resmethrin, or both. Statistical analysis of data was performed using JMP (v4.0; SAS Institute, Cary, NC). Transmission efficiency was analyzed using Pearson's $\chi^{2}$ analysis or Fisher's exact test, as indicated in the text. Persistence was analyzed using Pearson's $\chi^{2}$ analysis.

Host range studies. Large numbers of T. vaporariorum were allowed 24-h AAPs on $P$. wrightii source plants, as described and then transferring groups of 30 in daily

above. Following virus acquisition, whiteflies were briefly chilled at $4^{\circ} \mathrm{C}$ and transferred to clip cages for attachment to leaves. One clip cage containing 30 to 50 viruliferous whiteflies was attached to each of 10 seedlings per test plant species for an IAP of $48 \mathrm{~h}$. Approximately 30 to 45 days following initial test inoculation, the presence of virus in each test plant species was determined by nucleic acid spot hybridization (29), and by back-inoculation from test plants using 30 to 50 whiteflies per plant to $P$. wrightii, $N$. clevelandii, or $N$. benthamiana seedlings. These three species commonly are used as indicator hosts for criniviruses. ToCV symptoms on these indicator species are distinctive, consisting of interveinal yellowing and leaf brittleness on all three species.

Molecular analyses. Total nucleic acids were extracted according to the method of Dellaporta et al. (6), and extracts were stored at $-80^{\circ} \mathrm{C}$. Positive controls for ToCV consisted of ToCV-infected tomato, $N$. benthamiana, $N$. clevelandii, or $P$. wrightii. Negative controls consisted of virus-free plants of these and of test species. RT-PCR was used to amplify the 773nt CP ORF of ToCV (28) using primers described in Segev et al. (22). Total nucleic acid extracts (as well as positive and negative controls and reagent blanks) were reverse-transcribed using MMLV reverse transcriptase (Promega Corp., Inc., Madison, WI) with reaction conditions of $37^{\circ} \mathrm{C}$ for $90 \mathrm{~min}$, and cDNA was amplified with Taq DNA polymerase (Promega Corp., Inc.). Amplification conditions consisted

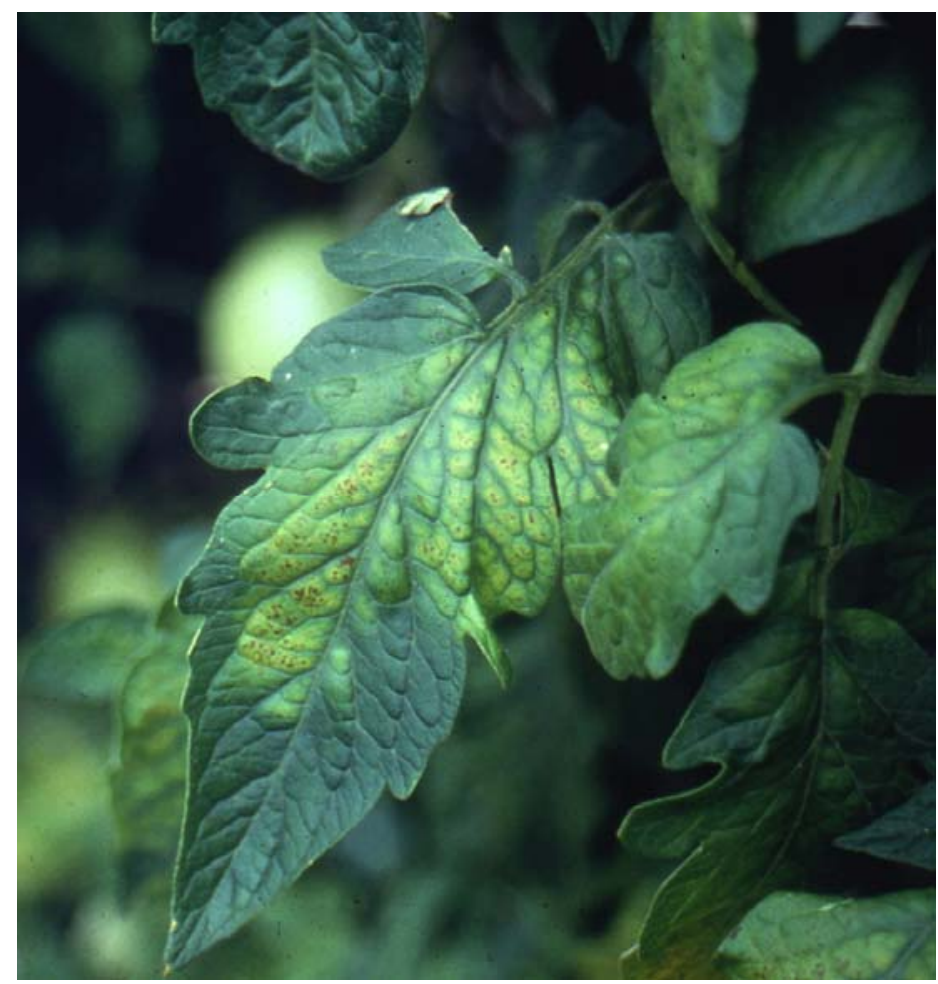

Fig. 1. Tomato chlorosis virus symptoms on tomato showing interveinal chlorosis and slight upward curling of leaves. 
of 5 min of denaturation at $95^{\circ} \mathrm{C}$, followed by 35 cycles of $95^{\circ} \mathrm{C}$ for $1 \mathrm{~min}, 55^{\circ} \mathrm{C}$ for 1 min, and $72^{\circ} \mathrm{C}$ for $1 \mathrm{~min}$, with a final extension at $72^{\circ} \mathrm{C}$ for $10 \mathrm{~min}$. RT-PCR reaction products were separated by electrophoresis in $1 \%$ agarose gels and stained with ethidium bromide to determine the products were cloned using the TOPO TA Cloning Kit (pCRII-TOPO; Invitrogen, Carlsbad, CA) and used to transform Esgen] or NovaBlue cells [EMD Biosciences, Madison, WI]) using standard conditions. Plasmids were prepared with the Qiagen Plasmid Mini Kit prior to sequencing. DNA sequencing was conducted by the University of Florida DNA Core Laboratory, Gainesville. Sequence alignment was conducted using MacVector 7.0 (Accelrys Inc., Carlsbad, CA) and Clustal W (23).

Nucleic acid spot hybriq3dizations were performed as described by Wisler et al. (29) using digoxigenin-11-UTP-labeled RNA transcript probes. Transcript probes representing the $\mathrm{CP}$ coding region of the ToCV-FL isolate $(22,28)$ and the HSP70h presence or absence of target bands. PCR cherichia coli (either TOP10 cells [Invitro-

coding region of TICV were used to test samples received from Florida, Louisiana, Colorado, Puerto Rico, and Israel using methods described by Wisler et al. (29). The TICV transcript probe was generated by RT-PCR amplification and cloning of a 325-nt segment of the HSP70h region of an Orange County, CA isolate of TICV using the primers and cloning method described above.

\section{RESULTS}

Host range and symptoms. ToCV induces a yellowing disease of tomato. Symptoms of ToCV in tomato can appear within 3 to 4 weeks after the appearance of the whitefly vector. Early symptoms on tomato consist of light yellowing between veins on older leaves, resembling a nutrient deficiency. As the disease progresses, the yellowing develops acropetally with intensified interveinal yellowing. Bronzing and necrotic flecking often occur within the yellowed areas, and the margins of leaves curl upward. Leaves eventually become thickened and crispy, and snap easily when bent. Symptoms generally

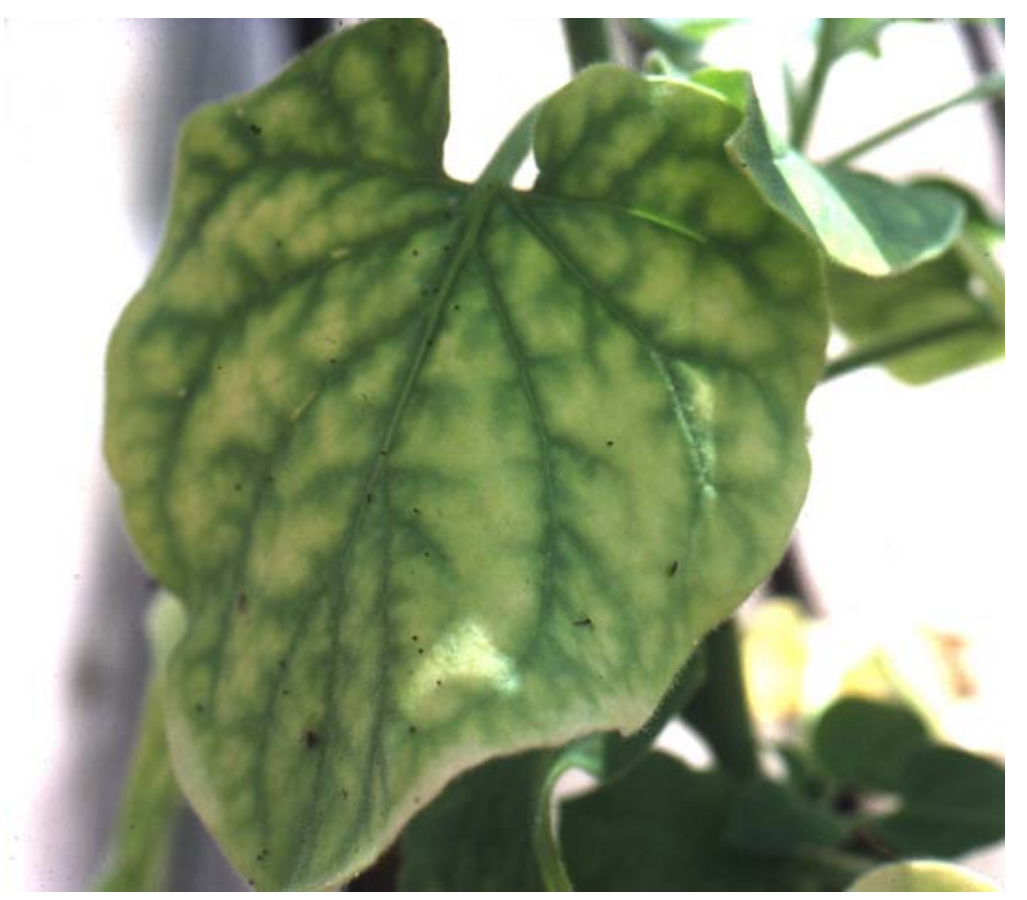

Fig. 2. Interveinal yellowing characteristic of Tomato chlorosis virus infection of Nicotiana glutinosa. develop on lower and middle leaves first, with upper parts of plants appearing healthy. Bronzing and necrosis of the older leaves are accompanied by a decline in vigor and reduction in fruit yield $(7,29)$. Symptoms of ToCV on tomato are indistinguishable from those induced by the related crinivirus, TICV (8).

Diagnostic hosts that can be used to distinguish the two criniviruses include $N$. glutinosa L., which develops a severe interveinal chlorosis when infected with ToCV (Fig. 2), but is not a host for TICV. Conversely, lettuce (Lactuca sativa L.) is not infected by $\mathrm{ToCV}$, but develops severe interveinal chlorosis when infected with TICV, resulting in nearly white leaves with green veins. In addition, the two viruses can be distinguished by symptoms induced on $N$. clevelandii and $N$. benthamiana. TICV produces a necrotic flecking with interveinal yellowing on both species, whereas ToCV only induces a mild interveinal chlorosis.

In addition to tomato, ToCV was found to infect a broad range of 24 plant species from seven different families (Table 1). Symptoms varied somewhat among hosts, but ToCV regularly induced severe yellowing or reddening symptoms, stunting, rolling, and brittleness of affected leaves in a wide range of weed and crop species. Species that naturally displayed red pigment tended to show intensification of red coloration in interveinal areas when infected. As the disease progressed, the discoloration developed acropetally. Plants tested that were unable to be infected by ToCV in the studies described here are listed in Table 2 .

Transmission efficiency by vector. Efficiency of transmission differed among the four whitefly species examined in these studies (Pearson, $P<0.0001$ ). The most efficient transmission was observed with B. tabaci biotype B (BTB) and T. abutilonea (TAB) (Fig. 3), which were equally efficient in transmission of ToCV to $P$. wrightii test plants, following a standard 24-h AAP on ToCV-infected $P$. wrightii and a 48-h IAP. ToCV was transmitted at low levels by individual whiteflies of both species, with $14 \%(7 / 50)$ transmission by individual BTB whiteflies and $8 \%(4 / 50)$ by individual TAB whiteflies. In addition,

Table 1. Plants susceptible to Tomato chlorosis virus, grouped by family

\begin{tabular}{ll}
\hline Family & \multicolumn{1}{c}{ Susceptible plants } \\
\hline Aizoaceae & Tetragonia expansa Murr. \\
Amaranthaceae & Gomphrena globosa L. \\
Apocynaceae & Vinca rosea L. \\
Chenopodiaceae & Beta macrocarpa Guss., Chenopodium capitatum (L.) Asch., C. murale L., Spinacia oleracea L. \\
Compositae & Callistephus chinensis (L.) Nees, Calendula officinalis L. \\
Plumbaginaceae & Limonium latifolium (J. E. Sm.) Kuntze \\
Solanaceaa & Capsicum annuum L., Cyphomandra betacea (Cav.) Sendt., Lycopersicon esculentum Mill., Nicotiana benthamiana Domin., \\
& N. clevelandii Gray, N. edwardsoni Christie \& D.W. Hall, N. glutinosa L., N. megalosiphon Huerch \& Muell., N. tabacum L., \\
& Petunia hybrida Vilm., Physalis alkekengi L., P. ixocarpa Brot., P. wrightii Gray, Solanum nigrum L., S. acaule Bitter \\
\hline
\end{tabular}

\footnotetext{
${ }^{a}$ Capsicum annuum was reported as a host in Spain (15), but separate replicated, controlled tests on jalapeno and bell pepper failed to result in transmission
} in the experiments described herein, suggesting possible varietal susceptibility. 
TAB and BTB transmitted at or near $100 \%$ efficiency when 40 whiteflies per plant were used in transmission experiments. Even 20 whiteflies per plant resulted in greater than $85 \%$ transmission by these vector species (Fig. 3).

B. tabaci biotype A (BTA), which is closely related to BTB, was significantly less efficient at transmitting ToCV (Fisher, $P<0.0001$ ) (Fig. 3). BTA, which was displaced in the United States by BTB, is a reasonably efficient vector of ToCV; however, unlike TAB and BTB, transmission was not observed with individual BTA whiteflies over the course of five experiments. Transmission efficiency increased with increasing numbers of BTA whiteflies per plant, but even 40 BTA whiteflies per plant only resulted in $74 \%$ (37/50) transmission.

T. vaporariorum (TVA) was the least efficient of the four vectors examined in these studies. No transmission was observed over five experiments with either 1 or 5 whiteflies, and only $4 \%$ (2/50) transmission occurred with 10 whiteflies (Fig. 3). Maximum transmission was observed with 40 TVA whiteflies, but was only $34 \%$ (17/50).

Persistence by vector species. The four vectors were compared for ToCV persistence, or the duration for which 30 whiteflies were able to transmit virus to host plants by daily serial passage following a 24-h AAP on ToCV-infected $P$. wrightii plants. ToCV clearly persisted longer in TAB than in the other species tested (Fisher, $P<0.0001$; Fig. 4). Transmission efficiency by TAB was $95 \%$ (61/64) within the first $24 \mathrm{~h}$ following virus acquisition (seven independent experiments). Efficient transmission continued 2 days after acquisition $(89 \%)$, but began to decrease by day three $(47 \%)$. No transmission was observed by TAB 6 days after acquisition. In contrast, persistence was much shorter in BTB $(P=0.2669$; Fig. 4), although this vector was equally efficient in transmission efficiency tests conducted the first day following a 24-h AAP (Fig. 3). Transmis-

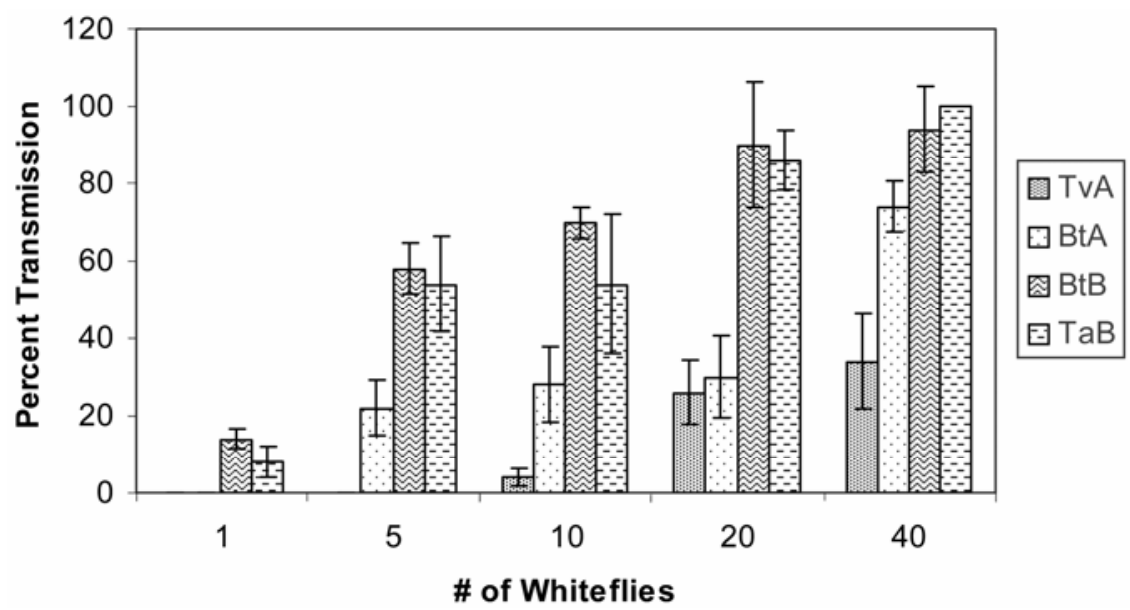

Fig. 3. Efficiency of Tomato chlorosis virus (ToCV) transmission differed among each of four different whitefly vectors $(P<0.0001)$. Percent transmission by each vector (48-h inoculation access period) is compared by number of whiteflies fed on Physalis wrightii test plants, following a 24-hour acquisition access period on ToCV-infected $P$. wrightii. Transmissions involved five independent replications of 10 plants each, per whitefly species, per number of whiteflies. Tva, Trialeurodes vaporariorum; BtA, Bemisia tabaci biotype A; BtB, B. tabaci biotype B; Tab, T. abutilonea.

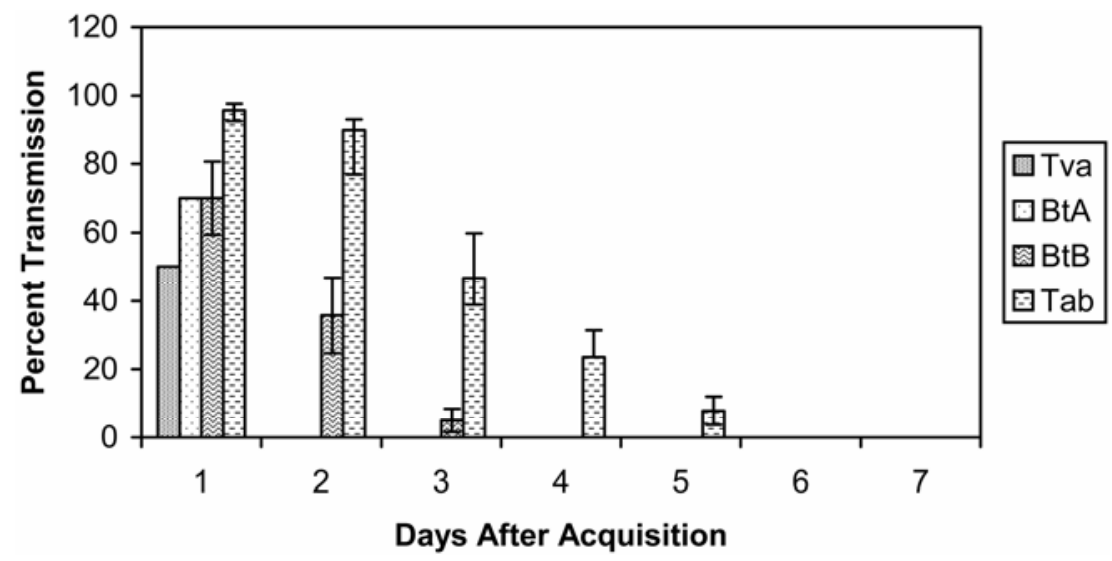

Fig. 4. Persistence of Tomato chlorosis virus (ToCV) in four different whitefly vectors. Percent transmission by each vector is compared by the number of days after virus acquisition during serial passage. Acquisition access periods consisted of 24-h mass feeding on ToCV-infected Physalis wrightii. Transmissions involved 30 whiteflies per plant in clip cages, moved to new plants each day for 7 days, with approximately 24-h inoculation access periods per transfer. Experiments with the most-efficient vectors, Trialeurodes abutilonea (Tab) and Bemisia tabaci biotype B (BtB), involved seven replications of 10 plants each per whitefly species (one replication with Tab consisted of only 5 plants per date rather than 10). Experiments with the less-efficient vectors, B. tabaci biotype A (BtA) and T. vaporariorum (Tva), involved two replications of 10 plants each.

Table 2. Plants not susceptible to Tomato chlorosis virus, grouped by family

\begin{tabular}{|c|c|}
\hline Family & Unsusceptible plants \\
\hline Apocynaceae & Vinca minor L. \\
\hline Balsaminaceae & Impatiens sultanii Hook. F. \\
\hline Caryophyllaceae & Dianthus barbatus L., D. caryophyllus L. \\
\hline Chenopodiaceae & Chenopodium amaranticolor Coste and Reyn. \\
\hline Compositae & $\begin{array}{l}\text { Coreopsis grandifolia Nutt., Lactuca sativa L., Cosmos bipinnatus Cav., Gazania rigens R. Br., Sonchus oleraceus L., } \\
\text { Tagetes patula L., Taraxacum officinale Webber, Zinnia elegans Jacq. }\end{array}$ \\
\hline Cruciferae & Capsella bursa-pastoris (L.) Medic. \\
\hline Cucurbitaceae & Citrullus vulgaris Schrad, Cucumis melo L., C. sativus L., Cucurbita pepo L. \\
\hline Euphorbiaceae & Euphorbia pulcherrima Willd. \\
\hline Fabaceae & Arachis hypogaea L., Phaseolus vulgaris L., Trifolium subterraneum L. \\
\hline Geraniaceae & Pelargonium domesticum Bailey \\
\hline Labiatae & Coleus blumei Benth. \\
\hline Malvaceae & Abutilon theophrastii Medic., Anoda abutiloides A. Gray, Gossypium hirsutum L., Malva parviflora L. \\
\hline Onagraceae & Godetia amoena G. Don \\
\hline Solanaceae ${ }^{\mathrm{a}}$ & Capsicum аппиит L., Datura stramonium L. \\
\hline
\end{tabular}

\footnotetext{
${ }^{a}$ Capsicum annuum was reported as a host in Spain (15), but separate replicated, controlled tests on jalapeno and bell pepper failed to result in transmission
} in the experiments described herein, suggesting possible varietal susceptibility. 
sion by BTB was at $70 \%$ at $24 \mathrm{~h}$ following virus acquisition, decreased to $36 \%$ by the second day following acquisition, was $5 \%$ by the third day, and no longer occurred 4 days following acquisition (seven independent experiments). Transmission of ToCV by BTA and TVA, although not examined as extensively as for the more efficient vector species, only occurred for the first $24 \mathrm{~h}$ after acquisition based on data from two independent experiments for each species. No transmission was observed by these species after the initial 24 $\mathrm{h}$ following acquisition (Fig. 4).

Genetic variation among diverse isolates. ToCV isolates were obtained from field- and greenhouse-grown plants from Florida, Colorado, Louisiana, Puerto Rico, and Israel. Total nucleic acids were isolated from symptomatic leaves infected with these geographically distinct isolates. A 487-nt section of the CP gene from each of these isolates was amplified, cloned, and sequenced. The region compared corresponded to nucleotides 4,358 to 4,845 of ToCV RNA2 (28), which showed an exceptionally high degree of genetic conservation among these isolates. All isolates from the continental United States and Puerto Rico shared at least $99 \%$ sequence identity at the RNA level. Comparison of deduced protein sequences revealed $100 \%$ identity among two isolates from Florida (AY903448 and DQ234675) and isolates from Colorado (DQ234674) and Louisiana (DQ234671). The isolate from Puerto Rico (DQ234672) shared 99\% amino acid sequence identity with the U.S. isolates and there was $98 \%$ amino acid sequence identity between the isolates from the United States and Israel (DQ234673). All Western Hemisphere isolates shared $98 \%$ nucleotide sequence identity with the Israel isolate, and the Puerto Rico isolate shared 97\% amino acid sequence identity with the Israel isolate.

\section{DISCUSSION}

One of the most remarkable biological properties of ToCV is its ability to be transmitted by four different whitefly vectors in two genera (29). This is highly unusual for a whitefly-transmitted virus. Most whitefly-transmitted viruses are transmitted by a single genus of whitefly. For example, begomoviruses are transmitted by $B$. tabaci, whereas criniviruses are transmitted by either B. tabaci or by Trialeurodes spp., but not by both. Among criniviruses, only ToCV is known to be transmitted by species within both genera. Although this has been known since the initial characterization of this virus, the efficiency of transmission by the different vector species had not been investigated. The studies presented herein demonstrate that ToCV can be transmitted with equal efficiency by both TAB and BTB, members of two different genera (Trialeurodes and Bemisia, respectively), and was achieved using individual whiteflies of either vector (Fig. 3). Equally interesting is the finding that transmission by other members of these genera was much less efficient. Both BTA and TVA can transmit ToCV, but single insect transmission was not observed with either of these vectors over five independent experiments. Transmission efficiency with 40 viruliferous whiteflies, a large number for an inoculation, was $74 \%$ for BTA and only $37 \%$ for TVA (Fig. 3).

A comparison of virus persistence in the two more efficient vectors, TAB and BTB, further illustrates the unique relationship ToCV shares with each vector. Although overall transmission efficiency is comparable between the two species (Fig. 3), persistence of ToCV in TAB far exceeds that in BTB (Fig. 4). Clearly, both of these more-efficient vectors retain virus in a transmissible form longer than either of the less-efficient vectors. However, TAB was able to transmit ToCV at a low level 5 days after feeding on an infected source, whereas BTB lost its ability to transmit after 3 days. ToCV persisted in BTA and TVA $24 \mathrm{~h}$ or less (Fig. 4). The poor retention observed in the less-efficient vectors is not surprising, but the variation in persistence among efficient vectors was unexpected. ToCV is a semipersistent virus, and a specific association between the virus and factors associated with the vector likely is required for transmission. One possible explanation is that the relationship may be more efficient with TAB than it is with BTB, resulting in better virus stability reflected by longer persistence.

A number of factors likely contribute to crinivirus transmission efficiency and virus persistence in whitefly vectors. Recent studies with another crinivirus, Lettuce infectious yellows virus (LIYV), demonstrated that transmission by BTA is influenced not only by the number of whiteflies used for transmission but also by the amount of virus available for transmission (18). The studies described herein confirm the effect of vector number on crinivirus transmission efficiency with multiple vectors, and also demonstrate that both efficiency of transmission and persistence can vary by vector species. Our results illustrate the unique relationships that occur between ToCV and its vector species, and suggest that ToCV may represent an evolutionary link between Trialeurodestransmitted criniviruses and those transmitted exclusively by Bemisia spp. This is supported by a phylogenic examination of crinivirus-encoded proteins (28). Although little is known about the role of crinivirusencoded proteins in whitefly transmission, evidence based on deletion mutants suggests that the minor coat protein $(\mathrm{CPm})$ of LIYV may be involved in its transmission by BTA (24). Interestingly, the CPm of ToCV is phylogenically situated between similar proteins of both Trialeurodes- transmitted and Bemisia-transmitted criniviruses (28). A comparison of protein similarity found comparable levels of relatedness for the ToCV CPm with the CPm of TVA-transmitted Beet pseudo yellows virus (49\%) and Potato yellow vein virus $(44 \%)$, as well as with the BTBtransmitted Sweet potato chlorotic stunt virus (51\%) and Cucurbit yellow stunting disorder virus (48\%) (28). It should be noted that other crinivirus-encoded proteins may be involved in whitefly transmission specificity as well; however, at this time, only the CPm has been implicated.

ToCV has a reasonably extensive host range, infecting at least 24 species from seven taxonomic families; and, although ToCV symptoms are indistinguishable from those induced by the related crinivirus, TICV, on tomato, the viruses can be distinguished readily by differential infection on a number of test plants. ToCV infects $N$. glutinosa L. and New Zealand spinach (Tetragonia expansa Murr.), whereas TICV does not. TICV infects shepherds-purse (Capsella bursa-pastoris L.), lettuce (Lactuca sativa L.), zinnia (Zinnia elegans Jacq.), and sowthistle (Sonchus oleraceous L.), whereas ToCV does not. In addition, $N$. clevelandii and $N$. benthamiana are excellent diagnostic hosts, due to differential symptom development. TICV produces necrotic flecking and interveinal yellowing on these hosts, but ToCV produces only the interveinal yellowing symptom. Lettuce and $N$. glutinosa are perhaps two of the best diagnostic hosts for differentiation of $\mathrm{ToCV}$ and TICV. N. glutinosa develops prominent interveinal chlorosis with ToCV infection (Fig. 2), but cannot be infected by TICV. Lettuce develops an almost white interveinal chlorosis when infected with TICV, but cannot be infected by ToCV. Interestingly, sweet pepper (Capsicum annuum L.) was reported as a naturally infected ToCV host in Spain (15), but separate, replicated, controlled tests on jalapeno and bell pepper failed to result in transmission in the experiments described herein, suggesting possible varietal susceptibility.

Many studies on criniviruses have focused on comparison of sequences of the HSP70h, due to its high level of conservation among not only criniviruses, but all members of the family Closteroviridae (11). The gene is selected because it usually can be amplified with degenerate primers by RT-PCR from most viruses within the Crinivirus genus, making it a useful diagnostic tool for quick identification of a crinivirus. An analysis of HSP70h sequences deposited in databases indicated high levels of sequence conservation among geographically diverse isolates of ToCV. The HSP70h coding regions of all isolates for which sequence was deposited in GenBank were 97 to $100 \%$ identical 
when compared among themselves (AJ968394, AJ968395, AJ968396, AY048854, AF215818, AF215817, AF233435, AF234029, and AY903448 [FL isolate]). Our studies did not examine the HSP70h coding region, because we were interested in looking at a potentially more variable region of the genome because it already was clear that the HSP70h region of ToCV isolates is highly conserved. The $\mathrm{CP}$ of ToCV shares much lower genetic similarity with other members of the genus Crinivirus (28), making it a good candidate. Interestingly, the $\mathrm{CP}$ also proved to be highly conserved, with all isolates sharing between 98 and $100 \%$ sequence identity at the amino acid level, and similar levels of conservation for viral RNA, based on analysis of a 488-nt sequence within the $\mathrm{CP}$ coding region. This suggests that relatively little genetic diversity exists among these ToCV isolates, and may indicate that they all originated from a single source. Four of the isolates in our study, Florida, Florida2, Colorado, and Louisiana, all were collected in the late 1990s (29). The deduced CP sequences of these isolates were identical. The Puerto Rico isolate was collected in 2001 (27), and the Israel isolate in 2004 (22). The minor variation observed between these latter two isolates could be the result of change since geographic separation. It is likely, based on geographic proximity, that the Israel isolate originated from European sources, whereas the Puerto Rico isolate most likely originated from sources in the United States. It is possible that all of the isolates for which sequence is available represent a single initial introduction into tomato followed by inadvertent dispersal of ToCV throughout the world.

Once ToCV is introduced to a new area, its broad vector transmissibility and substantial host range makes it difficult to control and eradicate. The prevalence of ToCV vectors varies among different vegetable production areas throughout the world. In some areas, BTB is the predominant vector whereas, in others, TVA is more abundant. Viruses that are transmitted exclusively by a single vector species will not become established in an area where that vector is not present, even if inadvertently introduced. ToCV, however, has the ability to be transmitted by a broad array of vector species, possibly even more than the four species examined here. Once introduced, ToCV can become established in weed, crop, and ornamental hosts found in many parts of the world, and potentially can move to new areas through vector transmission. This is of greatest concern in areas where TAB is found, due to the long persistence of $\mathrm{ToCV}$ in this vector; however, even the common BTB can transmit ToCV effectively even 2 days after acquisition.

This illustrates the importance of diagnosing and controlling criniviruses in agriculture. Many criniviruses, including
ToCV, resemble nutritional deficiencies, and often are misdiagnosed and disregarded until symptoms become widespread and the virus has become established in local weed populations. In addition, symptoms usually do not develop on infected host plants for at least 3 weeks and sometimes longer. Consequently, infected transplants easily can be moved from nurseries to field locations prior to the development of symptoms. A prudent approach would be to include ToCV, TICV, and other criniviruses in virus indexing programs not only for tomato, but also for other transplanted vegetable and ornamental crops. This ultimately may reduce the international movement of criniviruses and diminish their impact on agriculture.

\section{ACKNOWLEDGMENTS}

We thank A. Cortez and A. Anchieta for assistance with whitefly transmission studies and cloning and sequencing, respectively, and R. R. Martin and R. L. Gilbertson for critical review of the manuscript.

\section{LITERATURE CITED}

1. Accotto, G. P., Vaira, A. M., Vecchiati, M., Finetti Sialer, M. M., Gallitelli, D., and Davino, M. 2001. First report of Tomato chlorosis virus in Italy. Plant Dis. 85:1208.

2. Alzhanova, V. V., Hagiwara, Y., Peremyslov, V. V., and Dolja, V. V. 2000. Genetic analysis of the cell-to-cell movement of beet yellows closterovirus. Virology 268:192-200.

3. Alzhanova, V. V., Napuli, A. J., Creamer, R., and Dolja, V. V. 2001. Cell-to-cell movement and assembly of a plant closterovirus: roles for the capsid proteins and HSP70 homolog. EMBO J. 20:6997-7007.

4. Brown, J. K., Frohlich, D., and Rosell, R. 1995. The sweetpotato/silverleaf whiteflies: biotypes of Bemisia tabaci (Genn.), or a species complex? Annu. Rev. Entomol. 40:511-534.

5. Costa, H. S., and Brown, J. K. 1991. Variation in biological characteristics and in esterase patterns among populations of Bemisia tabaci (Genn.) and the association of one population with silverleaf symptom development. Entomol. Exp. Appl. 61:211-219.

6. Dellaporta, S., Wood, J., and Hicks, J. B. 1983. A plant DNA minipreparation: version II. Plant Mol. Biol. Rep. 1:19-21.

7. Dovas, C. I., Katis, N. I., and Avgelis, A. D. 2002. Multiplex detection of criniviruses associated with epidemics of a yellowing disease of tomato in Greece. Plant Dis. 86:1345-1349.

8. Duffus, J. E., Liu, H.-Y., and Wisler, G. C. 1996. Tomato infectious chlorosis virus-a new clostero-like virus transmitted by Trialeurodes vaporariorum. Eur. J. Plant Pathol. 102:219226.

9. Font, M. I., Juarez, M., Martinez, O., and Jorda, C. 2004. Current status and newly discovered natural hosts of Tomato infectious chlorosis virus and Tomato chlorosis virus in Spain. Plant Dis. 88:82.

10. Hanafi, A. 2002. Invasive species: a real challenge to IPM in the Mediterranean region? European Whitefly Studies Network Newsletter no. 13, p. 4. John Innes Centre, Norwich, UK.

11. Karasev, A. V. 2000. Genetic diversity and evolution of Closteroviruses. Annu. Rev. Phytopathol. 38:293-324

12. Liu, H.-Y., Cohen, S., and Duffus, J. E. 1992. The use of isozyme patterns to distinguish sweetpotato whitefly (Bemisia tabaci) biotypes. Phytoparasitica 20:187-194.

13. Liu, H.-Y., Wisler, G. C., and Duffus, J. E. 2000. Particle lengths of whitefly-transmitted criniviruses. Plant Dis. 84:803-805.

14. Louro, D., Accotto, G. P., and Vaira, A. M. 2000. Occurrence and diagnosis of Tomato chlorosis virus in Portugal. Eur. J. Plant Pathol. 106:589-592.

15. Lozano, G., Moriones, E., and Navas-Castillo, J. 2003. First report of sweet pepper (Capsicum aпnиum) as a natural host plant for Tomato chlorosis virus. Plant Dis. 88:224.

16. Napuli, A. J., Falk, B. W., and Dolja, V. V. 2000. Interaction between HSP70-homolog and filamentous virions of the beet yellows virus. Virology 274:232-239.

17. Navas-Castillo, J., Camero, R., Bueno, M., and Moriones, E. 2000. Severe yellowing outbreaks in tomato in Spain associated with infections of Tomato chlorosis virus. Plant Dis. 84:835-837.

18. Ng, J. C. K., Tian, T., and Falk, B. W. 2004 Quantitative parameters determining whitefly (Bemisia tabaci) transmission of Lettuce infectious yellows virus and an engineered defective RNA. J. Gen. Virol. 85:2697-2707.

19. Peremyslov, V. V., Hagiwara, Y., and Dolja, V. V. 1999. HSP70 homolog functions in cell-tocell movement of a plant virus. Proc. Natl. Acad. Sci. USA 96:14771-14776.

20. Prokhnevsky, A. I., Peremyslov, V. V., Napuli, A. J., and Dolja, V. V. 2002. Interaction between long-distance transport factor and Hsp70-related movement protein of Beet Yellows Virus. J. Virol. 76:11003-11011.

21. Satyanarayana, T., Gowda, S., Mawassi, M, Albiach-Marti, M. R., Ayllon, M. A., Robertson, C., Garnsey, S. M., and Dawson, W. O. 2000. Closterovirus encoded HSP70 homolog and P61 in addition to both coat proteins function in efficient virion assembly. Virology 278:253-265.

22. Segev, L., Wintermantel, W. M., Polston, J. E., and Lapidot, M. 2004. First report of Tomato chlorosis virus in Israel. Plant Dis. 88:1160.

23. Thompson, J. D., Higgins D. G., and Gibson, T. J. 1994. CLUSTALW: improving the sensitivity of progressive multiple sequence alignment through sequence weighting, positionspecific gap penalties and weight matrix choice. Nucleic Acids Res. 22:4673-4680.

24. Tian, T. Y., Rubio, L., Yeh, H. H., Crawford, B., and Falk, B. W. 1999. Lettuce infectious yellows virus: in vitro acquisition analysis using partially purified virions and the whitefly Bemisia tabaci. J. Gen. Virol. 80:1111-1117.

25. Tsai, W. S., Shih, S. L., Green, S. K., Hanson, P., and Liu, H. Y. 2004. First report of the occurrence of Tomato chlorosis virus and Tomato infectious chlorosis virus in Taiwan. Plant Dis. 88:311

26. Wintermantel, W. M. 2004. Emergence of greenhouse whitefly (Trialeurodes vaporariorum) transmitted criniviruses as threats to vegetable and fruit production in North America. APSnet feature. American Phytopathological Society, St. Paul, MN. Online publication.

27. Wintermantel, W. M., Polston, J. E., Escudero, J., and Paoli, E. R. 2001. First report of Tomato chlorosis virus in Puerto Rico. Plant Dis. $85: 228$

28. Wintermantel, W. M., Wisler, G. C., Anchieta, A. G., Liu, H.-Y., Karasev, A. V., and Tzanetakis, I. E. 2005. The complete nucleotide sequence and genome organization of Tomato chlorosis virus. Arch. Virol. 150:22872298.

29. Wisler, G. C., Li, R. H., Liu, H.-Y., Lowry, D. S., and Duffus, J. E. 1998. Tomato chlorosis virus: A new whitefly-transmitted, phloem limited, bipartite closterovirus of tomato. Phytopathology 88:402-409.

30. Zinovkin, R. A., Jelkmann, W., and Agranovsky, A. A. 1999. The minor coat protein of Beet yellows closterovirus encapsidates the $5^{\prime}$ terminus of RNA in virions. J. Gen. Virol. 80:269-272. 